\title{
Sustainability Reporting and Company Financial Performance: Evidence from an Emerging Market
}

\author{
${ }^{1}$ Eranga W.A., ${ }^{2}$ Wijesinghe M.R.P. \\ ${ }^{1,2}$ Department of Finance, University of Kelaniya, Sri Lanka. \\ Ierangaweerakondaarachchi@gmail.com, ${ }^{2}$ ruwanmrp@kln.ac.lk
}

\begin{abstract}
The main objective of this study is to examine the level of compliance to the sustainability practices and investigate the impact of sustainability reporting on the financial performance of Public Listed Companies in Sri Lanka. Sustainability disclosures were measured using social, economic, and environmental sustainability initiatives, and the company performance was measured through Return on Equity (ROE), Return on Assets (ROA), and Return on Sales (ROS). The study becomes original by applying an appropriate index to measure the sustainability reporting compared to the existing indexes used in Sri Lanka and applying the latest GRI 20 guidelines. In addition, the panel data regression model was employed to analyse the data from 2012 to 2019 . The results suggest that social sustainability reporting has a significant positive impact on company performance measured through ROE. Henceforth, company managers, directors, and investors should focus more on fulfilling and considering the Social Sustainability Guidelines.
\end{abstract}

Keywords: Global reporting initiatives, company financial performance, sustainability reporting, Sri Lanka.

\section{Introduction}

Sustainability report is a report published by a company or organization about the economic, environmental, and social impacts caused by its everyday activities. The sustainability report also presents the organization's values, governance model and demonstrates the link between its strategy and its commitment to a sustainable global economy (Global Reporting Initiatives, 2020). Sustainability reporting can be considered as synonymous with other terms for non-financial reporting; triple bottom line reporting, corporate social responsibility (CSR) reporting, and more. It is also an intrinsic element of integrated reporting, a more recent development that combines financial and non-financial performance analysis. (Global Reporting Initiatives, 2020)

The annual financial and non-financial disclosures of most listed companies disrespect multiple dimensions of corporate value or corporate social responsibility to the stakeholders. However, civil society pressure group, non-government organization group, government regulations, and corporate governance codes, green consumer pressure, and other similar pressure groups make it imperative for a corporate body that needs to survive and create wealth to consider corporate sustainability reporting disclosure to take care of the needs of various stakeholders (Olanrewaju, 2016). 
However, investigating the impact of sustainability reporting in emerging markets is still scarce, and it is still in its early stages compared to developed countries (Nur, et al., 2016). When considering the Sri Lankan context, studies on sustainability reporting have limited to the banking, finance, and insurance sectors (Silva, 2018; Athukorala \& Tilakasiri, 2018)

The evidence on sustainability reporting and financial performance appears to be inconsistent, and it's an unresolved argument as it provides contradictory findings. For example, in the previous studies, there has been a positive impact (Bayoud, 2012) negative impact (Brammer, 2006) and sometimes there has been no significant impact (Jones, 2005). Thus, it appears that the conclusions arrived at are mixed and often contradictory (Margolis, 2003).

With this backdrop, this study attempts to investigate the impact of Sustainability Reporting on Financial Performances of top sixty market capitalized Sri Lankan Listed Companies, including thirteen different sectors which represent the Sri Lankan stock market. Furthermore, this study effort to develop an index to identify the sustainability reporting practices used to assess the compliance level of the sustainability reporting practices in the Sri Lankan context. This form of index development has been widely accepted by other studies such as Social responsibility reporting (Nur, et al., 2016); Tilakasiri, 2012; Burhan \& Rahmanti, 2012).

Henceforth, the significance of the study is threefold. Firstly, the study uses the latest GRI 4, 2020 guidelines, and secondly, the dichotomous process is applied to measure the sustainability reporting in the Sri Lankan context ${ }^{1}$. Thirdly, employed a sample that represents the entire listed companies in Sri Lanka. Hence, these newest consequences could be helpful for both financial statement users deal with socially responsible companies and policymakers in defining corporate social responsibility incentives.

In rejoinder to the recognized disputes, the current study aimed to investigate the level of compliance to the sustainability practices and investigate the impact of sustainability reporting on company financial performance in the Sri Lankan context. Furthermore, an index for measuring the compliance with GRI guidelines was developed for companies listed on the CSE under guidelines issued by GRI 2020 .

The remaining part of the paper is organized as follows. The review of literature is discussed in section two and the methodology adopted in the study is presented in

${ }^{1}$ The first version of this paper was presented to the International Conference of Accounting and Finance Association of Australia and New Zealand (AFAANZ -2018), which was held in Auckland, New Zealand. The authors take this opportunity to thank for the valuable comments and suggestions given by the panel and the attendees of the conference. At this time, dichotomous process for the sustainability has not been applied in the Sri Lankan context. However, Silva (2018) has applied this process only for banking sector using the GRI 4, 2016. 
section three. The results and findings of the study are explained in section four. Finally, section five concludes the paper.

\section{Review of Literature}

\section{Sustainability reporting and sustainability dimensions}

There are numerous terms used to define the concept of corporate sustainability reporting contributions to social and environmental and consequences of business activity (Jenkins, 2001). Corporate sustainability, triple bottom line, sustainability, corporate responsibility, sustainability reporting, corporate social opportunity, corporate social responsibility, responsible business, corporate citizenship, Three Ps (profit, planet, people), sustainable development is some of the terms often related with corporate sustainability reporting. According to (GRI, 2013), a sustainability report is similar to financial reporting. Its compliance is voluntary. Sustainability reporting shows that the company takes responsibility for its economic, environmental, and social performance. It is similar to corporate social responsibility (CSR), which is voluntary in terms of compliance. Sustainable growth via sustainability reporting positively impacts a company's financial performance (Kasbun, 2016). Therefore, sustainability reporting may accurately and reasonably reflect a firm's financial performance (European Business Review, 2012).

Various studies over the last decade investigated the relationship between sustainability reporting and its effects on financial performance. Results ranged from positive to negative and even to insignificant relationships (Aggarwal, 2013; Bayoud, 2012; Brammer, 2006; Jones, 2005). Albu, (2011) has highlighted four benefits of sustainability reporting as follows; reduces direct costs (energy, materials, time loss, etc.); improves the productivity of workers (increased motivation, low absenteeism, reduced turnover); reduces management risk (easier access to credit, the increased value of the assets for investors, support by stakeholders, etc.); and improves the competitive image of the firm. Therefore, it can be identified that sustainability principles work throughout the organization by filtering their integration into planning and decision making, leading to improvement in sustainability performance. Hence, sustainability reporting would influence companies' performance and enhance their efficiency (Adams, 2007). Generally, potential investors look for lower risks and higher returns if they want to invest. Thus, sustainability reporting would increase share price in two ways: a) increasing revenue, net profit and thus inspiring better financial performance; $b$ ) assuring shareholders of the safety of their investments (Khaveh, 2012). According to Newport et al,. (2003), social investors, via their success, have revealed that sustainability is a decent indicator for a company's growth and its financial performance.

\section{Global reporting initiative:}

Global Reporting Initiative (GRI) is an international, non-profit, network-based organization. It is a multi-stakeholder effort to provide a comprehensive sustainability reporting framework that can be widely used by all companies 
worldwide. The sustainability reporting guidelines are the basis and spine of GRI's Framework. In addition, they promote transparent disclosure of company performance along with key sustainability aspects (GRI, 2020).

\section{Sustainability reporting and company performances:}

In the last two decades, there are many studies conducted in sustainability reporting and its impact on financial performance. Margolis, (2003) evaluated 127 published studies between 1972 and 2002 to study this relationship. Out of 127 studies, four studies analysed bi-directional relationships. In addition, 109 studies treated sustainability performance as an independent variable, out of which 54 showed a positive relationship, 7 showed a negative relationship, 28 showed a non-significant relationship, and 20 showed mixed results. Finally, in 22 studies, corporate sustainability was taken as the dependent variable, out of which 16 showed a positive relationship.

Orlitzky, (2003) found that CSR performance measures correlate with accountingbased measures than market-based indicators. Some researchers use accountingbased measures like Return on Assets (ROA), Return on Equity (ROE), Return on Sales (ROS), Profit before Taxation (PBT), Cash Flow from Operations (CFO), etc., to CSR. In contrast, others use market-based measures such as Stock Returns, Share Prices, Market Value Added (MVA), etc. However, prior research provide no clear and precise relationship between sustainability reporting and financial performance. The results are mixed and often contradictory (Aggarwal, 2013).

In the Sri Lankan context, Silva (2018) stated no significant difference in sustainability disclosures between listed banks and financial institutes. Therefore, the amount of disclosures has no significant influence on institutes' financial performance. This study has developed an index for the banks and financial institutes based on previous reporting guidelines (G4 guidelines) to perform a comparative analysis between the years 2017/2018 to the year 2016/2017. They have used 56 general standards, 13 economic standards, 23 environment standards and 27 social standards. However, this compilation of sustainability index is limited for the banking and financial sector companies, and they have not considered the GRI guidelines of 2020 .

Athukorala and Tilakasiri (2018) investigated the impact of sustainability practices on company performance, and they concluded that there is a significant positive impact on organization financial performance both with and without the effect of company size as a control variable. Nevertheless, their analysis is also limited to the banking, finance, and insurance sector with only one measure of financial performance. Therefore, in Sri Lanka, studies on sustainability reporting and company performance are available only for the banks and financial institutions, which may hinder decision makers' usefulness of such findings.

In summary, at the beginning of the literature review describes the importance of the sustainability concept and its emerging throughout the previous studies. Thereafter, some of the most important theoretical arguments regarding the sustainability concepts are described precisely as the agency, stakeholder, and 
legitimacy theories. Global Reporting Initiative (GRI) also discussed a worldwide, non-profit, network-based body that is determined to deliver a complete sustainability reporting basis that can commonly use altogether around the world. However, prior studies provide no clear conclusion on the impact of sustainability on company performance and are an unresolved issue. Especially in Sri Lanka, a limited number of studies are available, and the studies are restricted to investigate only the banking and finance sectors. Moreover, existing indexes to measure sustainability reporting can be enriched by applying a more suitable and wellaccepted index to measure the level of compliance to sustainability reporting practices. Henceforth, investigating this unresolved issue is paramount important for economic decision-makers.

\section{Methodology}

\section{Sample, data, and data collection}

As the sample of the study top, 60 capitalized companies were selected out of the listed companies at the Colombo Stock Exchange (CSE) at the end of 2019. These include companies from thirteen industrial sectors of the CSE, including banks, insurance and finance, plantations, diversified, construction and engineering, beverage, food and tobacco, telecommunications, and trading and manufacturing companies.

This study gathered secondary data from published sustainability reports (within annual reports or stand-alone reports), corporate social responsibility reports (annual reports or stand-alone reports), and company's websites. Company annual reports containing financial statements, financial disclosures, sustainability, and corporate social reports of the selected companies were used for this study. In addition, financial performance data and information were sourced from annual reports.

The data required for the GRI guideline categories (economic, environmental, and social disclosures are given in Appendix A) were measured using the sustainability index developed. The company's financial performance measures used in the study (ROE, ROA, and ROS) were calculated in excel spreadsheets after identifying the company's return, equity funds, total sales, total assets, and profits for the sample period.

\section{Hypothesis of the study}

The study's hypothesis has been developed based on the following theoretical arguments which have been referred to in the literature.

\section{Legitimacy theory}

Lindblom (1983) defines legitimacy as a condition that exists when an entity's value system is in harmony with society's value system. According to this theory, it is essential to meet the societal norms and expectations to ensure the firm's survival in the long-term. The proponents of legitimacy theory Patten (1992) argue that sustainability reporting tends to reduce the risk of regulatory actions and boycotts by stakeholders and strengthen the firm's license to operate. 


\section{Stakeholder theory}

According to Freeman, (1984), the stakeholder theory upholds that firms have accountability towards a broad range of stakeholders, apart from shareholders, i.e., creditors, customers, suppliers, employees, government, community, environment, future generations, etc. King, (2002) recognizes the significance of integrated sustainability reporting in strengthening the relationship between a firm and society in which it operates. Ignoring the stakeholder interests may taint firm's public image, which would unfavourably affect its financial performance.

\section{Agency theory}

The agency theory is based on the principal-agent relationship which exists between the owners and managers. It is well known that conflict of interest and information asymmetry exists between company managers (insiders) and shareholders \& other stakeholders (outsiders). In the absence of adequate public disclosure by companies, the amount of risk perceived by investors rises significantly (de Klerk, 2012). Sustainability reporting reduces information asymmetry and risk perceived by investors, increases market efficiency, and reduces the cost of capital to the firm (Olanrewaju, 2016). Based on these theories following hypotheses can be identified.

$\mathrm{H}_{1}$ : Economic sustainability reporting positively influences the financial performance of a company.

$\mathrm{H}_{2}$ : Environmental sustainability reporting positively influences the financial performance of a company.

$\mathrm{H}_{3}$ : Social sustainability reporting positively influences the financial performance of a company.

In order to achieve the study's main objectives, the following conceptual framework and the theories identified have been identified through the literature survey.

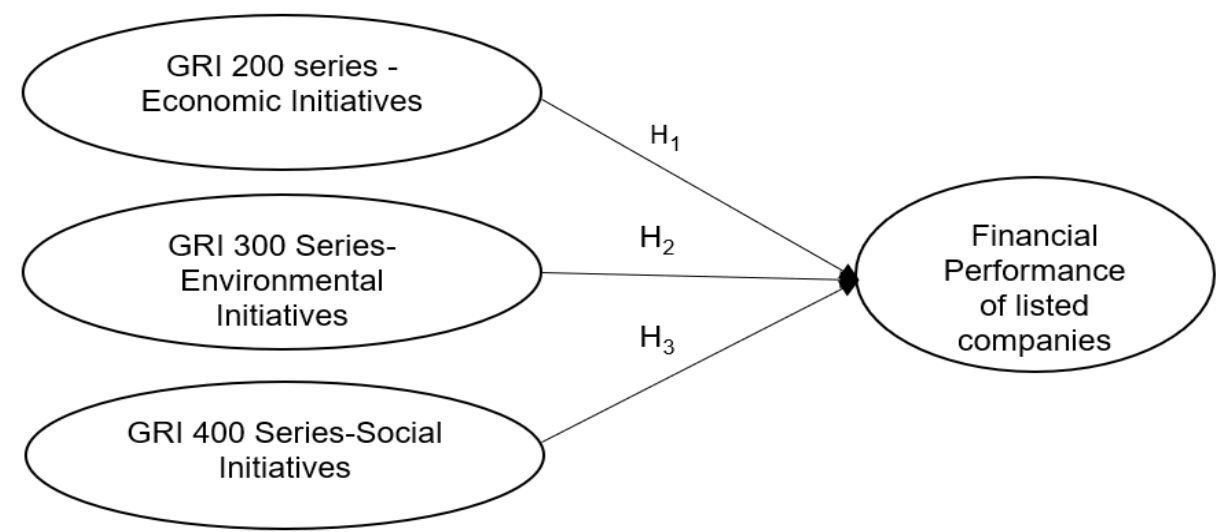

Figure I: Conceptual Framework 


\section{Operationalization of the variables}

Table I summarized the study's independent, dependent, and control variables, including how it has been calculated. The same variables have been taken by previous studies in numerous countries in several traditions. Mainly we apply the dichotomous approach introduced by Cooke \& Wallace (1989) and followed by subsequent scholars (Ngwakwe, 2009; Tilakasiri, 2012; Burhan \& Rahmanti, 2012; Nur, et al., 2016; Aggarwal, 2013).

\section{Table I: Summary of the Variables calculation}

\begin{tabular}{|c|c|c|}
\hline \multicolumn{3}{|c|}{ Dependent Variables } \\
\hline $\begin{array}{l}\text { Return on } \\
\text { (ROE) }\end{array}$ & Equity & Net income divided by Total shareholder's equity \\
\hline $\begin{array}{l}\text { Return on } \\
\text { (ROS) }\end{array}$ & Sales & Net income divided by Total Sales \\
\hline $\begin{array}{l}\text { Return on } \\
\text { (ROA) }\end{array}$ & Assets & Net income divided by Total Assets \\
\hline \multicolumn{3}{|c|}{ Independent Variables } \\
\hline \multicolumn{2}{|c|}{ Economic index } & $\begin{array}{l}\text { Number of Economic guidelines fulfilled by the company } \\
\text { divided by Number of Economic guidelines should be } \\
\text { fulfilled by the company as per the GRI }\end{array}$ \\
\hline \multicolumn{2}{|l|}{ Social index } & $\begin{array}{l}\text { Number of Social guidelines fulfilled by the company } \\
\text { divided by Number of Social guidelines should be fulfilled } \\
\text { by the company as per the GRI }\end{array}$ \\
\hline \multicolumn{2}{|c|}{ Environmental index } & $\begin{array}{l}\text { Number of Environmental guidelines fulfilled by the } \\
\text { company divided by Number of Environmental guidelines } \\
\text { should be fulfilled by the company as per the GRI }\end{array}$ \\
\hline Control variak & & Total Assets of the relevant company \\
\hline
\end{tabular}

\section{Data analysis and interpretation}

The analysis of the study's data for the period 2012 to 2019 has been done, employing the panel data analysis using the E Views. Before analysing the data, the stationarity of the data was checked using Levin, Lin \& Chu, Im, Pesaran \& Shin W-stat, ADF-Fisher Chi-square and PP-Fisher Chi-square tests. The results indicated that Total Assets, ROA, ROS are stationary at first difference while other variables are stationary at level. Furthermore, multicollinearity, Autocorrelation, and normality were also diagnosed. Finally, as the pre-tests, the appropriate method of analysis was tested using the Houseman test and found that the fixed effect model is suitable. The results of these diagnostic tests are attached with Appendix B.

\section{Results and Discussion}

The descriptive statistics have recorded a mean value 48 to 60 percent range, economic environmental and social disclosures suggesting an average level of 
disclosures in Sri Lankan listed companies. The results of the descriptive statistics are outlined in Table II.

Table II: Descriptive statistics

\begin{tabular}{lccc}
\hline $\begin{array}{l}\text { Sustainability } \\
\text { Index }\end{array}$ & Economic & Environmental & Social \\
\hline Mean & 0.552384 & 0.488885 & 0.599717 \\
Median & 0.666667 & 0.500000 & 0.736842 \\
Maximum & 1.000000 & 1.000000 & 1.000000 \\
Minimum & 0.142857 & 0.068571 & 0.052632 \\
Std. Dev. & 0.274641 & 0.280335 & 0.315346 \\
Skewness & -0.152342 & 0.109470 & -0.673638 \\
Kurtosis & 1.648468 & 1.807736 & 2.402583 \\
Jarque-Bera & 38.38943 & 29.38855 & 43.44117 \\
Probability & $0.0000^{* * *}$ & $0.0000 * * *$ & $0.0000 * * *$ \\
\hline
\end{tabular}

Note: $* * *$ Significant at $1 \%$ Level

One of the main objectives of the study is to develop a sustainability Index, and it was developed using the sustainability data obtained from the company's annual reports. An example of the Sustainability indices calculation process (dichotomous process) is given below. In addition, several guidelines have been taken based on the GRI guidelines.

Table III: Example of Sustainability indices calculation process (Dichotomous process) for XY PLC for five years.

\begin{tabular}{lccccc}
\hline XY PLC & \multicolumn{7}{l}{} \\
\hline & 2015 & 2016 & 2017 & 2018 & 2019 \\
\hline Social:19 & 18 & 14 & 14 & 17 & 16 \\
Economic:6 & 4 & 5 & 4 & 4 & 3 \\
Environmental:8 & 4 & 6 & 5 & 4 & 5 \\
Total: 33 & 26 & 25 & 23 & 25 & 24 \\
Social Index & 0.947368 & 0.736842 & 0.736842 & 0.894737 & 0.842105 \\
Economic Index & 0.666667 & 0.833333 & 0.666667 & 0.666667 & 0.5 \\
Environmental & 0.5 & 0.75 & 0.625 & 0.5 & 0.625 \\
Index & & & & & \\
\hline Total Index & 0.787879 & 0.757576 & 0.69697 & 0.757576 & 0.727273 \\
& & & & &
\end{tabular}

When considering the impact of sustainability reporting on company performance, only ROE exhibited significant impact among other variables, whereas ROA and 
ROS have no significance with sustainability disclosures. The summary of the results is presented in Table IV.

Table IV: Dependent variable: ROE (With Social, Economic and Environmental sustainability variables)

\begin{tabular}{lcccc}
\hline Fixed effect model: & Coef. & $\begin{array}{c}\text { P (Sig) } \\
\text { Without control } \\
\text { variable }\end{array}$ & Coef. & $\begin{array}{c}\text { P (Sig) } \\
\text { With control } \\
\text { variable }\end{array}$ \\
\hline Observation & 480 & - & 480 & - \\
No. of groups & 60 & - & 60 & - \\
Social (-1) & 0.020422 & 0.6673 & 0.0172 & 0.7158 \\
Economic (-1) & -0.073153 & 0.1592 & -0.06742 & 0.1932 \\
Environmental (-1) & 0.127977 & $0.0096^{* * *}$ & 0.13348 & $0.0068^{* * *}$ \\
Total Assets (-1) & - & - & $-7.94 \mathrm{E}-07$ & 0.0408 \\
Durbin Watson & - & 2.34 & - & 2.31 \\
$\mathrm{R}^{2}$ & - & 0.9017 & - & 0.9029 \\
Adjusted $\mathrm{R}^{2}$ & - & 0.8844 & - & 0.8854 \\
P-value (F) & - & $0.0000 * * *$ & - & $0.0000 * * *$ \\
\hline
\end{tabular}

Note: Fixed effect model, *** Significant at $1 \%$ Level

The results indicate a significant positive relationship between the environmental index and ROE when with and without the control variable but other than that, there is no significant relationship between other indexes.

However, a correlation between economic and environmental indexes (72\%) was noticed, hence it was also tested with omitting less fitted economic variables. The outcome of the multicollinearity results is given in Table $\mathrm{V}$.

Table V: Multicollinearity results

\begin{tabular}{lll}
\hline Sustainability Indexes & Economic & Environmental \\
\hline Environmental & 0.72 & 1 \\
Social & 0.58 & 0.56 \\
\hline
\end{tabular}

Henceforth, the impact of sustainability reporting on company performance was measured, using only Social and Environmental disclosures. The summary of the consequence is presented in Table VI.

Table VI: Dependent variable: ROE (With Social and Environmental sustainability variables)

\begin{tabular}{lcccc}
\hline Fixed effect model: & Coef. & $\begin{array}{c}\text { P (Sig) } \\
\text { Without control } \\
\text { variable }\end{array}$ & Coef. & $\begin{array}{c}\text { P (Sig) } \\
\text { With control } \\
\text { variable }\end{array}$ \\
\hline Observation & 480 & - & 480 & - \\
No. of groups & 60 & - & 60 & - \\
Social (-1) & 0.0213 & $0.0292^{*}$ & 0.0013 & 0.1707
\end{tabular}




\begin{tabular}{lcccc} 
Environmental (-1) & 0.0172 & 0.1304 & -0.001501 & 0.2119 \\
Total Assets (-1) & - & - & $-3.40 \mathrm{E}-11$ & 0.9998 \\
$\mathrm{R}^{2}$ & - & 0.8483 & - & 0.8562 \\
Adjusted $\mathrm{R}^{2}$ & - & 0.8219 & - & 0.8308 \\
P-value (F) & - & $0.0000 * * *$ & - & $0.0000 * * *$ \\
\hline
\end{tabular}

Note: Fixed effect model, *** Significant at $1 \%$ Level.

Results display a significant positive relationship between Social index and ROE when without the control variable, suggesting that Social and Environmental disclosures impact the company performance.

Given the sector-wise analysis, it can be identified that the diversified sector has recorded a high level of sustainability disclosures. In contrast, investment trust and construction and engineering sectors have given less attention to social disclosures. When seeing the economic disclosures, it indicates a mixed level of compliance by different sectors, whereas social and environmental disclosures stand at an average level in all sectors. The summary of the sector analysis is given below in table VII and figure II displays the company level compliance of overall sustainability disclosures.

Table VII: Sector-wise sustainability concerns

\begin{tabular}{|c|c|c|c|c|c|c|c|c|c|}
\hline \multirow{2}{*}{ Industry categories } & \multicolumn{3}{|c|}{ Social concerns } & \multicolumn{3}{|c|}{ Environmental concerns } & \multicolumn{3}{|c|}{ Economic concerns } \\
\hline & High & Medium & Low & High & Medium & Low & High & Medium & Low \\
\hline Construction and Engineering & $\ldots \ldots$ & $\ldots \ldots$ & $\because$ & $\ldots \ldots$ & $\odot$ & $\ldots \ldots$ & ;) & $\ldots \ldots$ & $\ldots \ldots$ \\
\hline $\begin{array}{l}\text { Beverage, Food and } \\
\text { Tobacco }\end{array}$ & $\cdots \cdots$ & $\ominus$ & $\cdots \cdots$ & $\cdots \cdots$ & $\ominus$ & $\cdots \cdots$ & $\cdots \cdots$ & 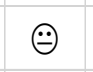 & $\cdots \cdots$ \\
\hline $\begin{array}{l}\text { Banks, Finance and } \\
\text { Insurance }\end{array}$ & $\cdots \cdots$ & $\odot$ & $\cdots \cdots$ & (:) & $\cdots \cdots$ & $\cdots \cdots$ & (:) & $\ldots \ldots$ & $\cdots \cdots$ \\
\hline Telecommunication & $\ldots \ldots$ & $\oplus$ & $\ldots \ldots$ & $\ldots \ldots$ & $\odot$ & $\ldots \ldots$ & $\ldots \ldots$ & $\odot$ & $\ldots \ldots$ \\
\hline Diversified & (:) & 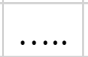 & $\ldots \ldots$ & (;) & $\ldots .$. & $\ldots \ldots$ & ;) & $\ldots \ldots$ & $\ldots .$. \\
\hline Healthcare & $\ldots \ldots$ & $\odot$ & $\ldots \ldots$ & $\ldots \ldots$ & $\odot$ & $\ldots \ldots$ & $\ldots \ldots$ & $\ldots \ldots$ & 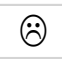 \\
\hline Manufacturing & $\ldots \ldots$ & 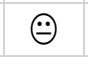 & $\ldots \ldots$ & $\ldots \ldots$ & $\oplus$ & $\ldots \ldots$ & $\ldots \ldots$ & $\odot$ & $\ldots \ldots$ \\
\hline Hotels and Travels & $\ldots \ldots$ & 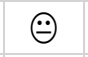 & $\ldots \ldots$ & $\ldots \ldots$ & $\odot$ & $\ldots \ldots$ & (:) & $\ldots \ldots$ & $\ldots .$. \\
\hline Oil palm & $\ldots \ldots$ & $\ominus$ & $\ldots \ldots$ & $\ldots \ldots$ & $\ominus$ & $\ldots \ldots$ & $\ldots \ldots$ & $\ldots \ldots$ & $\ddot{\theta}$ \\
\hline Land and property & $\ldots \ldots$ & 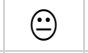 & $\ldots \ldots$ & $\ldots \ldots$ & $\Theta$ & $\ldots \ldots$ & $\ldots \ldots$ & $\ldots \ldots$ & $: 2$ \\
\hline Trading & $\ldots \ldots$ & $\ominus$ & $\ldots \ldots$ & $\ldots \ldots$ & $\ominus$ & $\ldots \ldots$ & $\ldots \ldots$ & $\ldots \ldots$ & 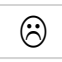 \\
\hline Power and Energy & $\ldots \ldots$ & $\odot$ & $\ldots \ldots$ & $\ldots \ldots$ & $\odot$ & ..... & $\ldots \ldots$ & $\Theta$ & $\ldots \ldots$ \\
\hline Investment Trust & $\ldots \ldots$ & $\ldots \ldots$ & $\ddot{\theta}$ & ..... & $\ldots \ldots$ & $\ddot{\theta}$ & ..... & $\ldots$. & 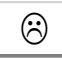 \\
\hline
\end{tabular}

Note: High - $100 \%$ to $70 \%$, Medium - $40 \%$ to $70 \%$, Low - below $40 \%$.

(:): High, :-: Medium, : $:$ : Low 


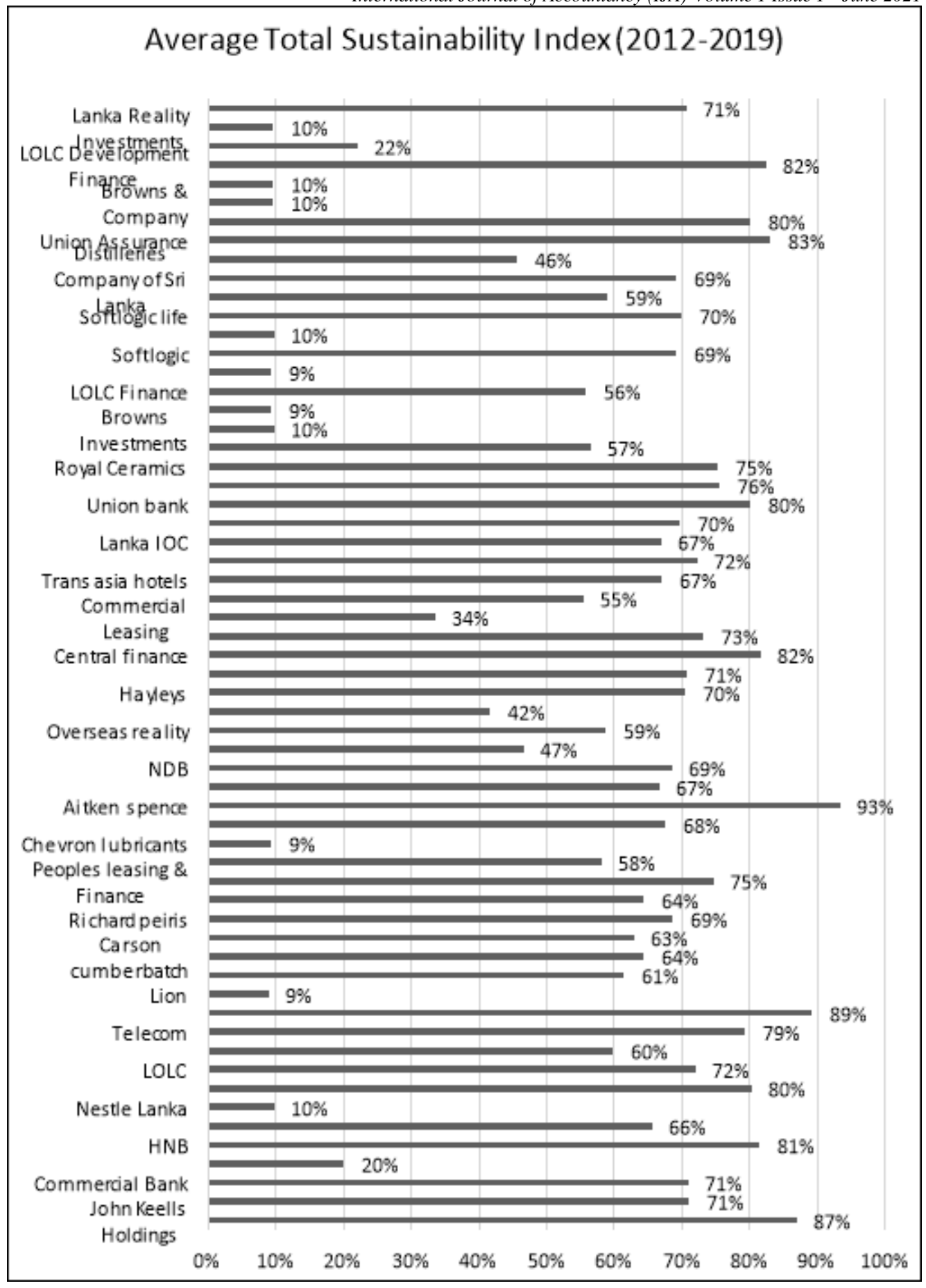

Figure II: Average total sustainability index (2012-2019) 


\section{Discussion and Conclusion}

Despite the availability of several studies relating to sustainability reporting and its impact on financial performance with mixed and often contradictory results, the present study investigates the same in the Sri Lankan context using GRI 4 guidelines of 2020 for top sixty capitalized listed firms. Furthermore, the study attempts to employ the dichotomous process to measure the sustainability practices in Sri Lankan context.

The findings depicted a mean value of 40 to 60 percent range of sustainability disclosures. Hence, it can be concluded that sustainability disclosers are still prevailing at an average level in Sri Lankan listed companies. Further, the study results revealed no impact from social, economic, environmental indexes on company financial performance measured by ROA and ROS, even though the company size is controlled. Nevertheless, the environmental sustainability index has a significant positive impact on ROE with and without control variable. However, when adjusting the multicollinearity effect, social sustainability index has a significant positive effect on company performance measured by ROE without a control variable. Therefore, it can be concluded that social sustainability disclosures are paramount for deciding the company performance at CSE.

However, Silva (2018) has concluded that there is no significant influence on institutes' financial performance from the sustainability disclosures in the listed banks and financial sector companies in Sri Lanka. With this, it seems that the sustainability practices and disclosures may behave differently in different sectors. Additionally, our findings are in line with the conclusion of Athukorala and Tilakasiri (2018), which investigated the impact of sustainability practices on company performance. Nevertheless, their conclusion is limited to the bank, finance, and insurance sector.

As suggested by the findings, except diversified sector, other sectors appear to have an average level of sustainability disclosures in the selected sectors. This could be due to the inadequacy of awareness among Sri Lankan stakeholders on the importance of sustainability reporting. Moreover, sustainability reporting is also unpredictable in Sri Lanka compared with other established countries due to the absence of adequate application and inconsistent sustainability reporting practices. It was found that some firms reported economic, social, and environmental sustainability in previous years but did not report in the next year.

Therefore, Sri Lankan companies should encourage to improve and upsurge alertness of the reputation of sustainability performance. Along with that, this study fulfills the gap by expanding this topic into various sectors, including banks, insurance and finance, plantations, diversified, construction and engineering, beverage, food and tobacco, telecommunications, and trading and manufacturing companies considering GRI 2020 latest guidelines in Sri Lankan capital market context. Therefore, managers, directors, and investors should focus more on fulfilling and assessing sustainability practices and disclosures to drive the performance of the entities. 
The present study reflected only the top 60 companies to the analysis, and therefore, one can extend the future studies covering the whole market for the analysis. Furthermore, there is a possibility of comparing the sustainability practices in different sectors to understand whether any industry-specific factors affect the impact of sustainability practices on company performance.

\section{Appendix A: Environmental and Social initiatives}

\begin{tabular}{|l|l|}
\hline \multicolumn{2}{|c|}{ Environmental initiatives } \\
\hline 1.Materials & 5.Emissions \\
\hline 2. Energy & 6.waste \\
\hline 3. Water and effluents & 7.Environmental compliance \\
\hline 4.Bio diversity & 8.Supplier environmental assessment \\
\hline
\end{tabular}

\begin{tabular}{|l|l|l|}
\hline \multicolumn{3}{|l|}{ Social Initiatives } \\
\hline 1). Employment & 8). Child labour & 15). Public policy \\
\hline 2). Labour management relations & 9). Forced or compulsory labour & 16). Customer health and safety \\
\hline 3). Occupational health and safety & 10). Security practices & 17). Marketing and labelling \\
\hline 4). Training and education & 11). Rights of indigenous people & 18). Customer privacy \\
\hline 5). Diversity and equal opportunity & 12). Human rights assessment & 19). Socio economic compliance \\
\hline 6). Non-discrimination & 13). Local communities & \\
\hline 7). Freedom of association and collective bargaining & 14). Supplier social assessment & \\
\hline
\end{tabular}

Source: GRI Guidelines (G4)

\section{Appendix B: Pre diagnosis test}

\section{Stationary test}

Dependent variables

\begin{tabular}{|c|c|c|c|c|c|c|c|c|}
\hline \multirow[t]{2}{*}{ Method } & \multicolumn{2}{|c|}{$\begin{array}{l}\text { Economic index } \\
\text { (At level) }\end{array}$} & \multicolumn{2}{|c|}{$\begin{array}{l}\text { Environmental } \\
\text { index (At level) }\end{array}$} & \multicolumn{2}{|c|}{$\begin{array}{l}\text { Social index (At } \\
\text { level) }\end{array}$} & \multicolumn{2}{|c|}{$\begin{array}{l}\text { Total assets (At } \\
\text { first difference) }\end{array}$} \\
\hline & Stat. & Prob. & Stat. & & Stat. & Prob. & Stat. & Prob. \\
\hline $\begin{array}{l}\text { Levin,Lin } \\
\& \text { Chu t* }\end{array}$ & -13.93 & 0.0000 & -13.05 & 0.0000 & -13.29 & 0.0000 & -34.11 & 0.0000 \\
\hline $\begin{array}{l}\text { Im,Pesaran } \\
\& \text { Shin W- }\end{array}$ & -10.64 & 0.0000 & -5.45 & 0.0000 & -3.70 & 0.0001 & -3.42 & 0.0003 \\
\hline $\begin{array}{l}\text { ADF- } \\
\text { Fisher } \\
\text { Chi-square }\end{array}$ & 333.21 & 0.0000 & 194.07 & 0.0000 & 181.25 & 0.0000 & 174.36 & 0.0009 \\
\hline $\begin{array}{l}\text { PP-Fisher } \\
\text { Chi-square }\end{array}$ & 289.53 & 0.0000 & 224.35 & 0.0000 & 210.61 & 0.0000 & 215.77 & 0.0000 \\
\hline
\end{tabular}

Method ROA (At first ROE (At level) ROS (At first 


\begin{tabular}{|c|c|c|c|c|c|c|}
\hline & \multicolumn{3}{|c|}{ difference) } & \multicolumn{3}{|c|}{ difference) } \\
\hline & Stat. & Prob. & Stat & Prob. & Stat. & Prob. \\
\hline Levin,Lin \& Chu t* & -21.70 & 0.0000 & -12.08 & 0.0000 & -33.88 & 0.0000 \\
\hline $\begin{array}{l}\text { Im,Pesaran \& Shin } \\
\text { W-stat }\end{array}$ & -4.307 & 0.0000 & -3.84 & 0.0001 & -7.334 & 0.0000 \\
\hline $\begin{array}{l}\text { ADF-Fisher } \\
\text { square }\end{array}$ & 205.693 & 0.0000 & 207.60 & 0.0000 & 249.99 & 0.0000 \\
\hline PP-Fisher Chi-square & 403.985 & 0.0000 & 254.30 & 0.0000 & 387.398 & 0.0000 \\
\hline
\end{tabular}

\section{Independent variables}

\section{Normality Test}

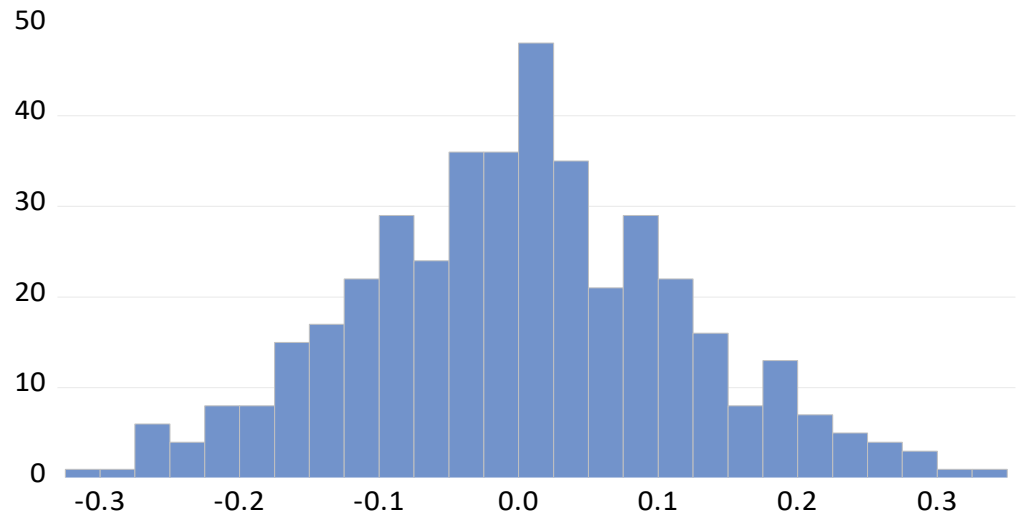

\begin{tabular}{|lc|}
\hline Series: Standardized Residuals \\
Sample 20132019 \\
Observations 420 \\
Mean & $1.32 \mathrm{e}-19$ \\
Median & 0.001490 \\
Maximum & 0.328975 \\
Minimum & -0.311086 \\
Std. Dev. & 0.116728 \\
Skewness & 0.100394 \\
Kurtosis & 2.911474 \\
& \\
Jarque-Bera & 0.842669 \\
Probability & 0.656171
\end{tabular}

In order to align with normality, this study used first difference of dependent variable while including control variable.

\section{Auto correlation, Heteroscedasticity and Multicolinearity}

In order to overcome the autocorrelation issue, study used first difference of the dependent variable. Durbin Watson value closer to two (1.7 - 2.3) was the benchmark while heteroscedasticity issue is not existing in this model. Existing Multicolinearity issue is addressed under table VI.

\section{Hausman Test: Random/Fixed effect model}

Cross section random probability value reflected as significant at $1 \%$ level, therefore, the study selected fixed effect model over the random effect model.

\section{ROE Model}

\begin{tabular}{|l|l|l|l|}
\hline Test summary & Chi-Sq. Statistic & Chi-Sq. d.f. & Prob. \\
\hline Cross section random & 234.265099 & 3 & 0.0000 \\
\hline
\end{tabular}




\section{References}

ACCA (2005), "Sustainability Reporting Guidelines for Malaysian Companies", Association of Chartered Certified Accountant.

Adams, C. A. (2007), "Making a difference: sustainability reporting, accountability and organisational change", Accounting, Auditing \& Accountability Journal, pp.382-402.

Aggarwal, P. (2013), " Impact of sustainability performance of company on its financial performance: a study of listed Indian companies", Global Journal of Management and Business Research Finance, Vol. 13 No. 2, pp.61-70.

Aggarwal, P. (2013), " Sustainability Reporting And Its Impact on Corporate Financial Performance: a literature review", Indian Journal of Commerce \& Management Studies.

Albu, N. A. (2011), "The implications of corporate social responsibility on the accounting profession: the case of Romania", Corporate Social Responsibility XIII, pp.221-234.

Athukorala, N.T. and Tilakasiri, K.K. (2018), "The Impact of Sustainability Reporting on Organization Performance - evidence from listed companies in bank, finance and insurance sector in Sri Lanka", 4th International Conference for Accounting Researchers and Educators, Retrieved from http://repository.kln.ac.lk/handle/123456789/19609.

Bayoud, N. K. (2012), "An Empirical Examination of the Relationship between Corporate Social Responsibility Disclosure and Organisational Performance".

Brammer, S. B. (2006), "Corporate Social Performance and Stock Returns".

Cooke, T. E., and Wallace, R. O. (1989), "Global surveys of corporate disclosure practices and audit firms: a review essay", Accounting Business Research Methods, Vol. 20 No. 77, pp.47-57.

De Klerk, M. (2012), "The value relevance of corporate responsibility reporting: south African evidence", Meditari Accountancy Research, Vol. 20 No. 1.

Dhaliwal, D. S. (2011), "Voluntary non-financial disclosure and the cost of equity capital: the initiation of corporate social responsibility reporting", The Accounting Review, Vol. 86 No. 1, pp.59-100.

Ecdes, R. I. (2012), "The Impact of a Corporate Culture of Sustainability on Corporate behavior and Performance".

Freeman, (1998), "A stakeholder theory of the modern corporation", Perspective In Business Ethics, p.144.

Freeman, R. E. (1984), "Strategic Management: a stakeholder approach", London Financial Times, Prentice Hall.

Friedman, A. (1982), "Foundations of modern analysis", Dover publications.

Gray, R. K. (1995), "Corporate Social and Environmental Reporting: A review of the Literature and Longitudinal study of United Kingdom Disclosure", Accounting, Auditing and Accountability Journal, Vol. 8 No. 2, pp.47-79.

GRI (2013), "Sustainability Reporting Guidelines", Global Reporting Initiatives, Version 3.1, Standard Disclosure: Performance Indicators, p. Retrieved from https://www.globalreporting.org/Pages/default.aspx .

IMA (2008), "Institute of Management Accountants". 
Jenkins, R. (2001), "Corporate codes of conduct: self-regulation in a global economy", United Nations Research Institute for Social Development.

Jones, S. (2005), "Notes of the University of Sydney Pacioli Society".

Kasbun, N. F. (2016), "Sustainability Reporting and Financial Performance of Malaysian Public Listed Companies", Institutions and Economies, pp.78-93.

Khaveh, A. N. (2012), "Voluntary sustainability disclosure revenue, and shareholders wealth - a perspective from Singaporean companies", Society for Business and Management Dynamics, pp.6-12.

King, M. E. (2002), "King Report on Corporate Governance for South Africa", Institute of Directors in Southern Africa.

Lindblom, C. (1983), "The concept of organisational legitimacy and is implications for corporate social responsibility disclosure", American Association Public Interest Section, Working paper.

Margolis, J. D. (2003), "Misery loves companies: rethinking social initiatives by business", Administrative Science Quarterly, Vol. 48 No 2, pp.268-305.

Newport, D. C., Chesnes T., Lindner A. S. (2003), "The "environmental sustainability" problem: Ensuring that sustainability stands on three legs", International Journal of Sustainability in Higher Education, pp.357-363.

Nur, Boon, \& Tze. (2016), "Sustainability Reporting and Financial Performance of Malaysian Public Listed Companies", Institutions and Economies, pp.78-93.

Olanrewaju, R. A. R. (2016), "Corporate sustainability reporting practice in an emerging market: a case of listed companies in Nigeria", Azarbaijan Journal of Economic and Social Studies.

Orlitzky, M. S. (2003), "Corporate social and financial performance: a meta analysis organization studies", pp.403-441.

Patten, D. M. (1992), "Intra-industry environmental disclosures in response to the Alaskan oil spill: a note on legitimacy theory", Accounting, Organizations and Society, pp. 471-475.

R, J. (2001), "Corporate codes of conduct: self-regulation in a global economy", United Nations Research Institute for Social Development.

Silva, D. (2018), "Sustainability Reporting and Its Impact on Financial Performance: a study of Sri lankan financial sector", $15^{\text {th }}$ International Conference on Business Management.

Tilakasiri, K. K. (2012), "Corporate Social Responsibility and Company Performance: evidence from Sri Lanka", Victoria University. Retrieved from https://vuir.vu.edu.au/21488/1/Korathotage Korath_Kamal_Tilakasiri.pdf 